AIR WAR COLLEGE

AIR UNIVERSITY

\title{
DEFINING A 21ST CENTURY AIR FORCE (SERVICES) BUSINESS MODEL
}

by

Danny E. Davis, Lt Col, USAF

\author{
A Research Report Submitted to the Faculty \\ In Partial Fulfillment of the Graduation Requirements \\ Advisor: Col Alan Hunt, Jr.
}

10 May 2014 


\section{DISCLAIMER}

The views expressed in this academic research paper are those of the author and do not reflect the official policy or position of the US government, the Department of Defense, or Air University. In accordance with Air Force Instruction 51-303, it is not copyrighted, but is the property of the United States government. 


\section{Contents}

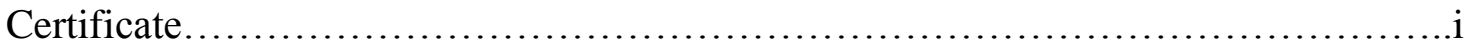

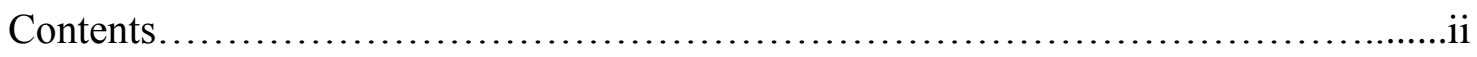

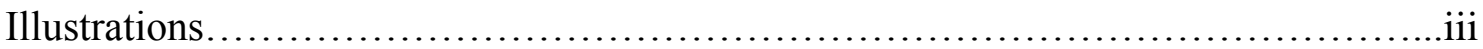

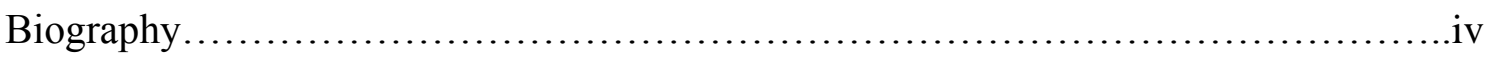

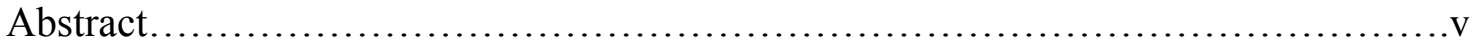

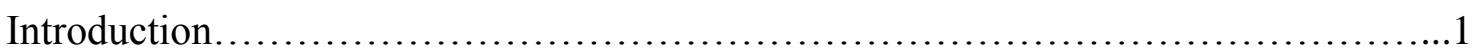

Part I: Why Change the FSS Conus NAF Activity Business Model....................

The Millennial Generation.....................................................9

Sequestration Impacts.................................................. 10

Failures of Services Transformation............................................ 10

Part II: How Should the Air Force Define a 21st Century Services Business Model.....11

Conclusion............................................................ 16

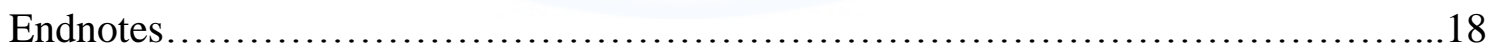

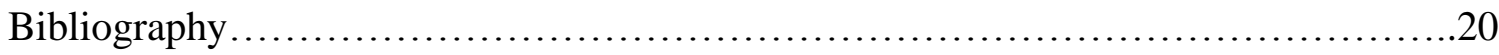




\section{Illustrations}

Page

Figure 1. Financial Status of Programs (Rolling 12 Month) as of 31 October 20135

Figure 2. Air Force Services CORE Programs 8

Figure 3. Today's Airmen (Millennial Generation Characteristics) 9

Figure 4. Force Support Squadron Community Services Flight Structure 14 


\section{Biography}

Lieutenant Colonel Danny E. Davis is assigned to the Air War College, Air University, Maxwell AFB, AL. Lieutenant Colonel Davis was commissioned through the University of Kentucky Air Force Reserve Officer Training Corps Program in 1994. He is a core personnel officer who has served in various duties in operations, training, plans, and international politicalmilitary affairs. He has held multiple staff assignments and served as a commander on four occasions. Prior to his selection to attend Air War College, he commanded the Force Support Squadron at Joint Base Charleston, South Carolina. 


\begin{abstract}
This paper addresses the need to define a new business model for the financially failing Continental United States (CONUS) morale, welfare, and recreation (MWR) nonappropriated fund (NAF) activities in the U.S. Air Force. It is broken down into two major parts -eliminating NAF activities that have sustained consistent financial losses and replacing those NAF activities with more relevant services on the installation.

The 40-year old CONUS base-level MWR business model for NAF activities is out of sync with the needs of today's Airmen (officer and enlisted) and their families. As a result of this outdated model, created for the needs of military members two generations ago, many NAF activities are failing financially because services offered are irrelevant to the desires of this generation. The Air Force attempted to resolve this issue through Services Transformation; however, that concept has largely failed because it was not a strategically comprehensive approach. Furthermore, it did not redefine the outdated services business model that has existed for decades. In addition, Services Transformation has neither generated the programming excitement necessary to keep the interest of today's Airmen and their families nor has it achieved the savings the Air Force had hoped to realize during these fiscally challenging times.

In order to overcome this dilemma, the Air Force (and Army) should develop a new business model by requesting the Army Air Force Exchange Service (AAFES) take lead on negotiating national and local community business partnerships. This new community business partnership model consists of public-private ventures (PPV) and/or third-party lease agreements (TPLA) that could replace the current Air Force services business model. PPV and TLPA partnerships will eliminate the need to keep failing NAF activities; replace those failed installation NAF activities with national and/or local food and retail businesses; save the Air
\end{abstract}


Force millions of dollars in lost NAF activity revenue; reduce NAF manpower, building infrastructure, and maintenance costs; and better serve the needs of today's Airmen and their families for many decades to come. 


\section{INTRODUCTION}

'Gentlemen, we have run out of money; now we have to think.'

--Sir Winston Churchill

It is now more imperative than ever for the Air Force to develop a new services business

model. Under the current model, NAF activities have lost millions of dollars in recent years, and if current financial loss activity is an indicator of future performance, then NAF activities will continue to lose millions of dollars on an annual basis in the years ahead. In addition, today's millennial generation is perhaps the most "unique" generation in decades because they have grown up in the information and technology age. Understanding this generation is important because Air Force millennial generation Airmen comprise 69 percent of today's Air Force, ${ }^{2}$ so they significantly contribute to the economic prosperity of any Air Force installation services program. Coupling the need to upgrade an outdated services business model with the necessity to meet the needs and desires of today's Airmen is reason enough to make changes; however, there is perhaps a more driving reason for developing a new model - funding constraints. Fiscally challenging times demand the Air Force find every single dollar it can to ensure the survival of Air Force readiness and modernization.

The Air Force has been negatively impacted with fiscal challenges since 2011, and as it projects budget shortfalls over the next decade, the Air Force must consider all saving options. Although Airmen readiness and modernization have come to the forefront during these difficult financial times, Airmen quality of life is a competing factor that the Air Force must consider.

The Air Force maintains its most valuable weapon system is its people, and it places a lot of emphasis on quality of life. However, fiscal demands have forced Air Force leadership to make some difficult choices that will have some now unforeseeable second and third order 
effects for years to come. Airmen understand these fiscally constrained times call for sacrifices and that quality of life will be impacted in the name of readiness and modernization; however, the Air Force must be careful when it comes to cutting quality of life programs to find a quick savings with little regard for long-term implications. The Air Force has always placed great emphasis on quality of life and recruits have come to expect that focus. The long-term implications of cutting any quality of life program could impact recruiting and retention years down the road because the motivations and expectations of today's generation are still being defined. "Internal military research shows that today's young people are less likely to want to serve in the military compared to past generations." 3 If Airmen recruiting and retention become Air Force problems, readiness will be impacted too.

Therefore, the Air Force must take a comprehensive approach in looking at MWR quality of life programs and decide if cutting those programs now will be worth the returns in the years to come. Instead of chipping around the edges of MWR to find savings in the name of Services Transformation, the Air Force should develop a more strategic approach. A holistic approach that upgrades the services business model is in order. A new business model could save the Air Force millions of dollars in NAF manpower and building infrastructure expenses as well as generate NAF revenue opportunities across CONUS bases. With more budget cuts on the horizon, the only way to predict what Air Force quality of life programs will look like five or ten years from now is to strategically shape them today by developing a new services business model now.

This paper addresses the need to define a 21st Century Air Force (services) business model. The CONUS base-level MWR business model created 40 years ago for NAF activities is out of sync with today's Airmen and their families because the model has not kept up with their 
needs and desires. As a result of this outdated model, many NAF activities are failing financially. The Air Force attempted to resolve this issue through Services Transformation; however, that concept has largely failed because it was not a comprehensive Air Force approach. Services Transformation has not generated more exciting programs for today's Airmen, and it has not achieved the savings the Air Force had hoped to realize to meet its fiscal demands. To overcome this dilemma, the Air Force should change its services business model by eliminating failing NAF activities at CONUS locations and requesting AAFES take lead on establishing national and/or local food and retail community business partnerships. This new community business partnership model in the form of PPV and/or TPLA will save millions of dollars and better serve the needs and desires of today's Airmen.

\section{THESIS}

The existing services business model does not meet the needs of today's millennial generation or a fiscally-constrained Air Force, so the Air Force should divest itself of NAF programs that lose money and convince AAFES to establish national and local community business partnerships that meet the needs and desires of Airmen and their families.

\section{Part I}

\section{Why change the FSS CONUS NAF activity business model?}

There is a need to change the CONUS NAF activity business model (from henceforth all references to NAF activities in this paper will imply CONUS only locations since overseas NAF businesses models have different variables) because the current model of taking care of Airmen and their families developed decades ago is no longer relevant to today's Air Force consumer, and many NAF activities across the Air Force are losing thousands of dollars on a monthly basis. The implication of these monthly losses is that the activities and services provided are no longer 
wanted by base customers. Essentially, millennial Airmen vote with their dollars but only if the activities provided meet their needs and desires.

MWR activities are broken down into three categories determined by their effect on the military mission and ability to generate revenue. The three categories are: Category A (mission sustaining activities); Category B (community support activities); and Category C (revenuegenerating activities).

Category B programs are a combination of appropriated funds (APF) and NAF dollars and although many of them are not self-sustaining operations, those Category B activities receive APF supplementation to help support their ability to exist and provide service. Category B activities include: arts and crafts; bowling centers (less than 13 lanes); outdoor recreation; recreational swimming pools; information, ticketing, and tours services; automotive skill development; child development services/child, youth, and school services; entertainment (music and theater). Category $\mathrm{C}$ programs operate solely with NAF dollars and those business activities must be self-sufficient. Category $\mathrm{C}$ activities provide recreational opportunities and have less impact on readiness. These activities include: golf courses; military clubs; bowling centers (over 12 lanes); bingo; aquatic centers; and food, beverage, and entertainment operations; aero clubs; and skeet/trap operations. ${ }^{4}$

Below is a chart listing Air Force Major Command NAF activities (Category B and C) by type for last fiscal year through 31 October $2013 .^{5}$ According to this chart, the Air Force lost millions of dollars on a rolling twelve month basis through 31 October 2013. The chart indicates there are trending losses in Air Force Clubs, Child Development Centers, and Golf Courses across several Major Commands (MAJCOMs). 


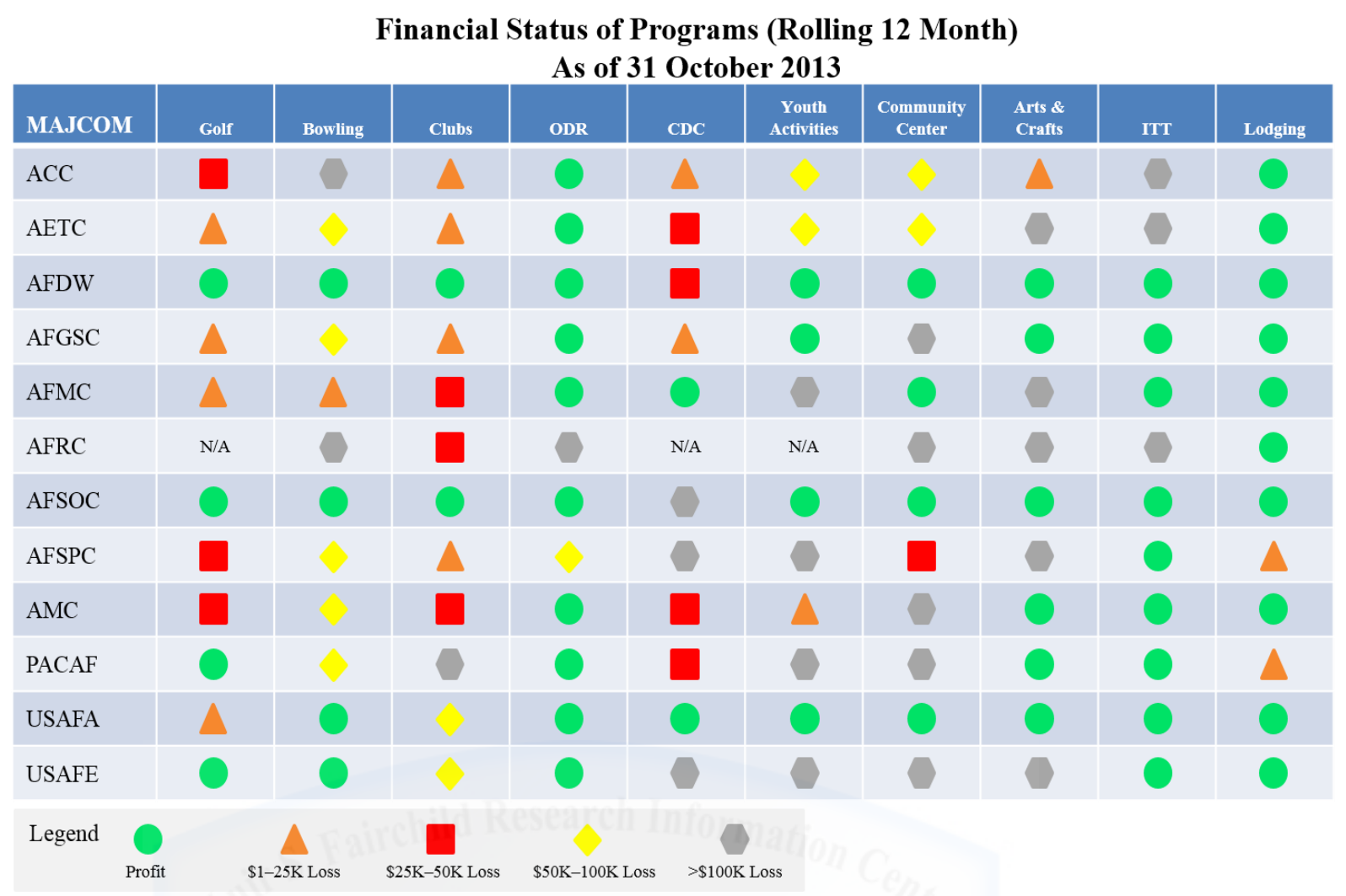

(Figure 1)

The symbols on the chart above represent losses for bases in that MAJCOM. For example, in Air Combat Command (ACC) the golf course is listed with a red square indicating a loss greater than $\$ 100,000$ during this time period. This indicates one or more golf courses in ACC may have lost that total amount.

According to the data in this chart and subsequent charts from this source broken down by MAJCOM, both Category B and Category C losses by activity tally a sum total of $\$ 5,725,000$. The total Category $\mathrm{C}$ losses alone during this time period were $\$ 4,650,000$. This source also reveals NAF business activity losses by base. According to the data, 25 Air Force golf courses out of 54 total golf courses lost money during this same time period. That equates to a total golf course loss of forty-six percent. There were 36 Air Force clubs out of 67 total clubs that lost money during this period. That equates to a fifty-four percent loss for all CONUS 
clubs. Consider the implications of tens of thousands of NAF dollars in salaries and retirement paid to thousands of regular and flex (part time) employees at these 25 golf courses and 36 clubs. Consider the implications of tens of thousands of APF dollars in the building infrastructure and maintenance costs for all those NAF facilities. If all financially-failing NAF activities were closed, the Air Force could save millions of dollars in NAF losses, employee costs, APF building infrastructure, and maintenance costs. The Air Force could realize these savings on an annual basis.

The bottom-line result is millions of NAF and APF dollars are being spent each year to keep financially unsuccessful NAF activities operating across the CONUS at a loss. The Air Force has essentially paid hundreds of NAF employees tens of thousands of NAF dollars and invested tens of thousands of APF dollars in NAF building infrastructure maintenance costs to lose $\$ 4.65$ million for one year in 119 NAF business activities across all state-side installations. The Air Force can no longer afford to maintain the status quo for services activities. Outside Air Force installation gates, businesses that fail to generate enough revenue to pay expenses cannot survive. They would have to change business practices to generate enough customer demand for their service or product. There is no logical reason why the Air Force should operate any differently, especially during austere fiscal times when there are better business-model options available.

According to the data, Category $\mathrm{C}$ activities suffer the most losses. The implication is the business model used to operate those activities has become irrelevant to customers. If an installation's Category C activities operate at a loss, then gains generated by Category B and other Category C activities must compensate for those losses from the base's overall MWR fund at the expense of base Airmen and their families. Every dollar required to support a losing NAF 
activity could have been used to provide other desired MWR activities. So the end result is over $\$ 4.6 \mathrm{M}$ per year is spent to support non-value activities instead of activities to increase resilience and morale. This financial practice has been happening for decades without major reform.

For the purposes of this paper and based on the data, the focus for a business model change should be on "non-core" Category B and C activities as identified by Services Transformation. The "non-core" financially-failing Category B activities include: bowling centers (less than 13 lanes); arts and crafts centers; automotive skill development centers; and information, ticketing, and tours services. The "non-core" financially failing Category C activities include: bowling centers (over 12 lanes); military clubs; aero clubs; skeet/trap operations; golf courses; and food, beverage, and entertainment operations. "[Category C] activities must be self-sustaining and charge fees based on the revenue requirements of the base MWR fund and fees charged for similar services in the surrounding local community.",6 Category $\mathrm{C}$ activities, especially golf courses and base clubs, operate at thousands of dollars in losses on a monthly basis across most CONUS installations. ${ }^{7}$

These "non-core" Category B and Category C programs were identified as vulnerable for closure under Services Transformation; however, base commanders, may have been reluctant to close activities without programs to replace failing activities. They may have been concerned about a decrease in morale and in the base communities they were leading. Below at figure 2 is a table listing of major Category B and Category C or "non-core" programs under Services Transformation..$^{8}$ In the table, the activities from ITT to Aero Club are "non-core" programs, and they are the NAF activities suffering most of the financial losses. Services Transformation successfully identified the problem, but the Air Force has not developed a business model solution. 


\section{CORE Programs}

\begin{tabular}{|c|c|c|c|c|c|c|c|c|}
\hline AF Services Programs & $\begin{array}{c}\text { Contribution to } \\
\text { Readiness }\end{array}$ & Utilization & Satisfaction & $\begin{array}{c}\text { Ensure } \\
\text { health and } \\
\text { fitness }\end{array}$ & $\begin{array}{l}\text { Help Airmen } \\
\text { regenerate }\end{array}$ & $\begin{array}{l}\text { Make } \\
\text { "routine" } \\
\text { easier }\end{array}$ & $\begin{array}{l}\text { Build sense } \\
\text { of } \\
\text { community }\end{array}$ & $\begin{array}{l}\text { Help cope } \\
\text { with militiry } \\
\text { life }\end{array}$ \\
\hline Fitness & High & High & Medium & $\checkmark$ & $\checkmark$ & & & $\checkmark$ \\
\hline Child / School Age Care & High & High & Medium & & & $\checkmark$ & & $\checkmark$ \\
\hline APF Dining & High & High & Low & $\checkmark$ & & & $\checkmark$ & \\
\hline A\&FRC's & High & Medium & High & & & $\checkmark$ & & $\checkmark$ \\
\hline Library & High & High & High & & $\checkmark$ & $\checkmark$ & & \\
\hline $\begin{array}{l}\text { Outdoor Recreation } \\
\text { Programs }\end{array}$ & High & High & High & $\sqrt{ }$ & $\checkmark$ & & $\sqrt{ }$ & \\
\hline Youth Programs & Medium & Medium & Medium & & & $\checkmark$ & $\sqrt{ }$ & \\
\hline ITT & Medium & Medium & High & & $\sqrt{ }$ & & & \\
\hline Bowling & Medium & Medium & High & & $\checkmark$ & & $\sqrt{ }$ & \\
\hline Club & Medium & High & Low & & $\checkmark$ & & $\checkmark$ & \\
\hline Community Center & Medium & Low & Medium & & $\checkmark$ & & $\checkmark$ & \\
\hline Auto Hobby & N/A & Low & Medium & & $\checkmark$ & & & \\
\hline Arts \& Crafts & N/A & Low & Medium & & $\checkmark$ & & & \\
\hline Golf & $\mathrm{N} / \mathrm{A}$ & Low & Medium & $\sqrt{ }$ & $\sqrt{ }$ & & & \\
\hline Aero Club & N/A & Low & Low & & $\sqrt{ }$ & & & \\
\hline
\end{tabular}

Sources: Caring for People survey; DoD MWR survey; 113 AF Services Surveys; Airmen Interviews; Mission Requirements Evaluation; Airmen Needs Evaluation; AF Service Utilization \& Alignment Evaluation; Corporate, Education \& Military Best Practices; Generational Research; Resiliency Research

(Figure 2)

The implication is that Airmen and their families vote by spending or not spending dollars at these activities. Therefore, considering this trend of losses by activity over several years, evidence supports that the Air Force needs a new business model because it can no longer afford to sustain a $\$ 4.65 \mathrm{M}$ loss on a rolling 12-month basis. Again, this amount only accounts for "non-core" Category C activity losses. It does not include the "non-core" Category B activity losses or the millions of dollars in personnel and building infrastructure costs to operate those failing activities. These losses and costs are rationale driving the need for a new model. Furthermore, the millennial generation, representing 69 percent of today's Air Force population, have needs and desires that are different than those supported by the existing model. 


\section{The Millennial Generation}

There has been much debate about how to define the millennial generation. Millennials were born between 1980 and $1995 .{ }^{9}$ Some of their many characteristics indicate they enjoy multi-tasking and are extremely savvy with electronics. Even though it is well known that millennials are technologically savvy, the Air Force has not upgraded its NAF activities or programs that promote electronics or technology as a theme of recreation. Therefore, the Air Force needs to recognize purchasing habits and preferences of millennials from a marketing perspective in order to develop a relevant services model. Based on research conducted by the millennial focused Barkley marketing group, "Millennials align to brands with a purpose." ${ }^{10}$ In other words, millennials prefer national brands, and this is important because base NAF activities are not associated with national brands; they are independent, no-name operations.

Millennial shopping habits indicate that youthful and future patrons want more on-line and interactive programs. In a recent world-wide survey conducted by the company, eMarketer, 40 percent of male millennial respondents indicated they would buy everything online if they could. $^{11}$ The chart below lists more millennial characteristics. ${ }^{12}$

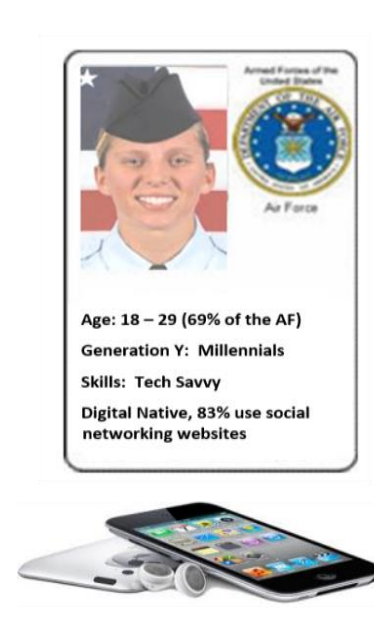

facebook.

\section{Today's Airmen}
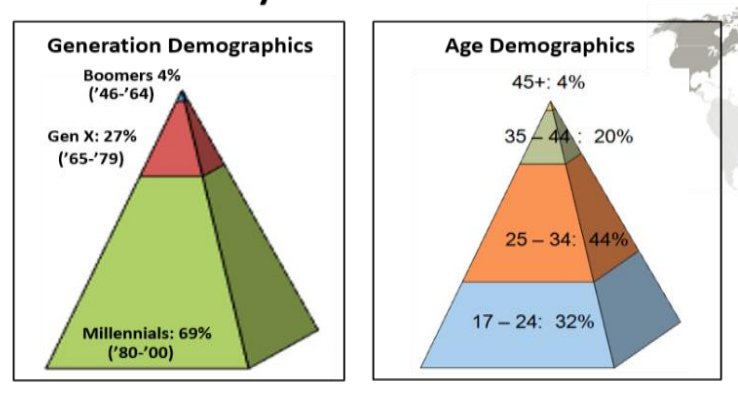

Millennial's Defining Characteristics:

Tech Savvy:

Multi Tasking:

Cut their teeth on technology and internet

Listen to music, work on a computer, while watching TV

Diverse:

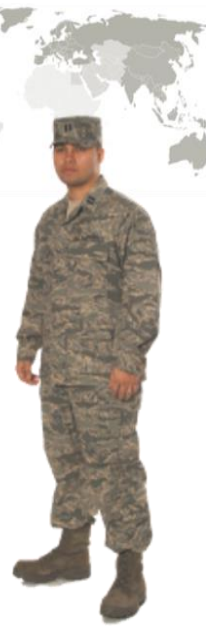

(Figure 3) 


\section{Sequestration Impacts}

Sequestration mandated that the Department of Defense decrease costs by $\$ 470$ billion

over a 10 year period. ${ }^{13}$ It has forced funding reductions and provided additional justification to develop a new NAF activity business model. The benefit of sequestration drives efficiencies. However, the Services, Manpower, and Personnel career field has unsuccessfully attempted to adjust its failing NAF business model by continuing to implement Services Transformation.

\section{Failures of Services Transformation}

Services Transformation was an attempt to solve the services business model dilemma; however, there was no comprehensive Air Staff approach to creating a new model. For example, NAF transformation focused on the accounting system while food transformation only focused on campus feeding and included both dining hall and NAF food activities. There was also an effort to identify services activities as core, enhanced or noncore. In an August 2013 Armed Forces Press Service article entitled, "Air Force offers potential model for future MWR programs, ${ }^{14}$ it provided several examples of successful attempts to upgrade services to better meet the demands of today's millennial generation; however, it failed to identify a strategic approach. This is the current dilemma.

Although Services Transformation does not solve the dilemma, the Air Force has identified the need for a business model upgrade due to decades of declining appropriated fund support in dollars and manpower. ${ }^{15}$ The Air Force has been contemplating a new business model for some time. However, the problem has been developing one that fits the Air Force mission. There are several constraints that must be taken into consideration. One constraint is that the majority of people who work on base do not live on base. Another constraint is NAF businesses cannot compete with off-base competition when it comes to marketing and programming. An 
additional constraint is the inability of "outsiders" to access and use the services. A final constraint is that there are several important factors that inhibit base NAF activities from operating like "real" businesses such as outdated regulations and business concepts.

These factors combined have ensured NAF services offered to Airmen have remained unsuccessful for decades. With these difficult issues in mind, it is time for the Air Force to develop a new model.

\section{Part II}

\section{How should the Air Force define 21st Century services business model?}

The Air Force should develop a new services business model leveraging community business partnerships in the form of Public-Private Ventures (PPV) and/or Third-Party Lease Agreements. During this business model upgrade, the Air Force must simultaneously consider the wartime and in-garrison training requirements for its services airmen and remember to consider the force support career field's 17 doctrinal enduring capabilities when negotiating community business partner options. Perhaps the Air Force should re-examine the enduring capabilities to determine if it could assume more risk, but at a minimum, the Air Force should take these capabilities into consideration. This consideration is necessary because the enduring capabilities drive services airmen readiness. Additionally, the Air Force should establish a fulltime single airman coordinator at each CONUS installation to serve and program for the needs of dorm residents by encouraging the use of programs offered under this new model. The costs of hiring full-time coordinators at CONUS installations could be paid for with funds saved from reduced manpower costs associated with the closing of failed NAF activities. There are enough airmen in CONUS base dorms to support this recommendation, but remote and isolated locations may be an exception. 
The PPV model recommends installations partner with national and local businesses to operate on the installation. Partnerships could also be formed off the installation; however, the Air Force must take caution and not neglect operations on base. Otherwise, base communities will deteriorate which will defeat the force support squadrons' mission to build a sense of community. One of the many benefits of the PPV model is government investment costs are very low. While there are times when the host organization may "chip in" a small amount of funds, those funds are typically provided for the purpose of boosting or creating the infrastructure necessary to accommodate the installation with a desired concept or brand. The bulk of the funding (usually 75 percent or more) is provided by the brand operator, franchisee or parent organization. Their funding provides for the brand specific build out in the space, décor, equipment, signage, et cetera, and all other items necessary to operate in spaces. ${ }^{16}$ The agreements are typically written for three five-year periods, and the awardee or licensee will pay a percentage of monthly sales as concession income. Therefore, the Air Force would have low investment costs and a monthly income as benefits to hosting these agreements, and base customers would get to enjoy the best of today's commercial sector food service and retail providers.

This PPV concept has been proven, and it is currently in existence and successfully operating at some Navy, Marine Corps, and Coast Guard installations. This model also exists at the Pentagon. NEXCOM leads the Pentagon food operation and the Department of Defense Concessions Committee (DoDCC) leads the Pentagon's retail operation. NEXCOM's food operation increased by fifteen million dollars in FY13 for a 148 percent sales increase compared to FY01 when the PPV began. DoDCC's retail operation increased by eight million dollars in FY13 for a 64 percent sales increase compared to FY01 when the PPV began. ${ }^{17}$ 
Ironically, AAFES has recently initiated this PPV concept at their Army led Fort Bliss, Texas base. Initial feedback indicates that it has been successful. However, there is one major limitation to establishing PPV: the size of the base population must be large enough for businesses to take interest. The implication is that this concept may only provide an option for Air Force led joint bases and other bases that have extremely large populations. The Air Force could discuss this stipulation with AAFES and decide which bases meet the population requirements to establish PPV. At least, this is one option that provides an alternative to the current model, which is broken.

The other community business partner option is a Third-Party Lease Agreement (TPLA). A TLPA resembles a lease that a tenant would sign with any National Mall Owner. AAFES is currently exploring this type of community business partnership to save expenses. By treating their real estate or vacant space in a similar fashion as a commercial landlord would outside the gate, AAFES maximizes its potential use of space. Under this concept, AAFES would work with commercial real estate brokers to negotiate what they have historically operated themselves. By outsourcing restaurants/retail facilities, the licensee would be responsible for the furniture, fixtures, and equipment; the overhead for operating expenses, personnel, and cost of goods sold. AAFES would take a fee from the licensee, and the Air Force would need to negotiate its fee with AAFES to feed its MWR fund. The monetary-exchange details can be negotiated, but the strategic concept is the important starting point if the Air Force desires to eliminate failing "noncore" NAF activities.

TPLA provide more flexibility than PPV because the size of the base population is not the "sole" factor for businesses to form an agreement. Businesses factor marketing demographics into TPLA, and although the base population number would be a factor, there 
would be additional factors such as base patron age groups and gender statistics. While PPV would be contingent upon larger base populations, TPLA could provide small to medium bases more national and local business options. This concept would require AAFES to engage national and local community businesses to determine what they need to warrant establishing their business operations on an installation. TPLA could provide an additional option for the Air Force to replace failing NAF activities.

Once the Air Force decides to pursue PPV for large base populations, pursue TPLA for all of its CONUS bases, or pursue a combination of both PPV and TPLA depending on the base size, then the Air Force can set a timeline to begin closing failed "non-core" NAF activities. This decision to close NAF activities will promote additional savings for the Air Force by reducing the size of the force support squadron.

From October 2012 to October 2013, there were 119 out of 313 or 38 percent of NAF activities in CONUS that lost money. ${ }^{18}$ The majority of those failed activities were associated with the Force Support Squadron's Community Services Flights (CSFs).

Eliminating failed NAF activities will decrease the size of CSFs. If most NAF activities in the CSFs are losing money at an installation, and PPV and/or TPLA businesses can be brought in to replace NAF activities, then the majority of the CSFs could be eliminated. If a few NAF activities are succeeding at an installation, the CSFs may remain but as the flight begins to decrease in size, the Air Force could redefine the flight as a section and decrease APF and NAF manpower costs associated with its operation. Decreased APF and NAF manpower costs across CONUS CSFs could result in millions of dollars being saved. 
Below is the current CSF structure. ${ }^{19}$

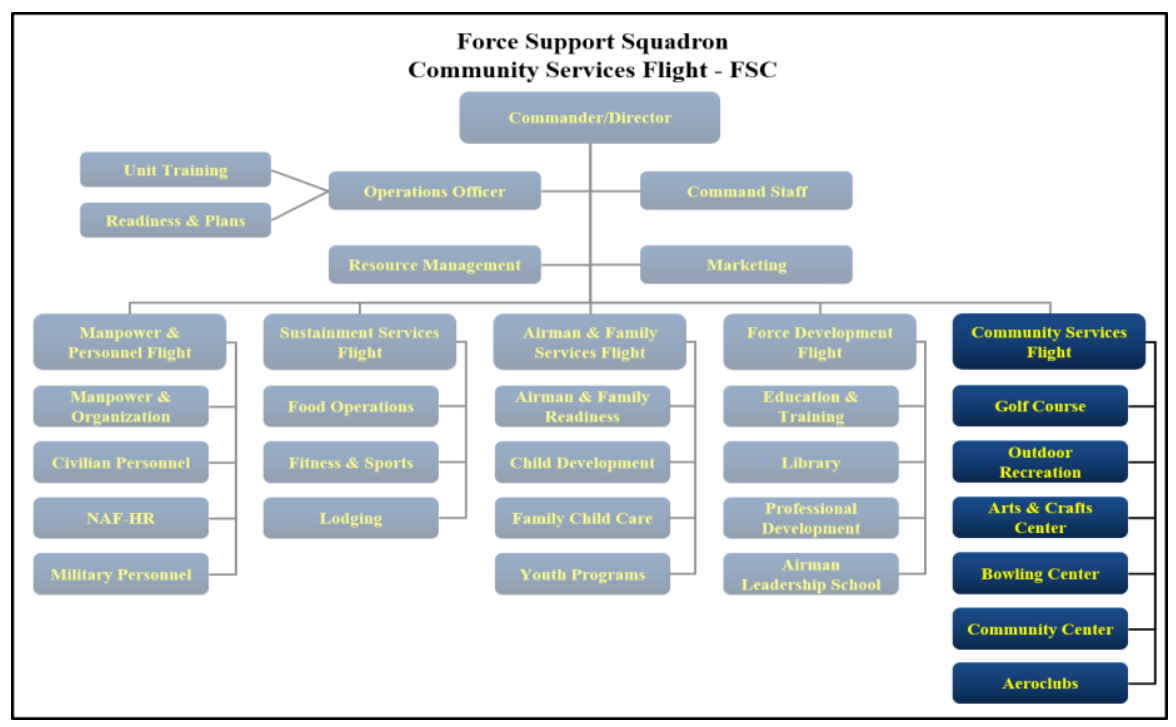

(Figure 4)

As NAF activities close and PPV and/or TPLA businesses are added to installations, the Air Force must consider a couple of war-time services airmen (Enlisted) skill sets.

The top priority that needs to be considered when developing the 21 st Century Air Force services business model is to remember the Air Force services airmen (military blue suiters) wartime and in-garrison requirements. There was no mention of readiness requirements for services airmen when Services Transformation was developed, but it is important for the warfighter. All services airmen are trained in garrison to deploy to the war zone and stand up a bare-base operation. If services airmen do not receive the required training in garrison this will severely limit their capability to stand up recreational activities and "regenerate" warfighters in the deployed zone.

The second priority that needs to be considered when developing this new model is that any additional national or local business activities invited to operate on the installation must meet the intent of A1's force support enduring capabilities. Although the current structure of force support squadron NAF activities was developed decades ago, wartime training requirements 
have been modeled around that structure. If new national and local businesses are brought onto an installation and services airmen train on organize, train, equip (OTE) employment and nonappropriated fund instrumentality (NAFI) capabilities in an education with industry type arrangement, then these new business activities must meet the doctrinal intent of A1's force support enduring capabilities. The Air Force A1 community could ensure the 9 enduring capabilities with a war fighter focus, 4 capabilities focused on home station families, and 4 capabilities across the Air Force are taken into consideration when the Air Force implements this new model.

One final priority should include establishing a champion manager to focus entirely on single airmen in the dorms and all single Airmen 26 years old and younger. The Air Force has developed a program known as the Single Airman Initiative (SAI) along the lines of this same mission. The SAI coordinator is an additional duty for a member of the Community Services Flight at most installations. Some funds have been allocated to the SAI coordinator to program events for airmen in those age categories. However, the Air Force needs to place greater emphasis on this position as a direct liaison to millennial Airmen. Establishing a full-time single airmen coordinator (henceforth referred to as "Coordinator") has been done at one location in the entire Air Force. The FSS leadership at that location saw a need to establish a full-time position in January 2012. The results of that effort were phenomenal. One major success story was a growing population of airmen who were visiting the Coordinator (office located in the dorms) as events were orchestrated. Dorm airmen would inform the Coordinator on what programs they wanted to enjoy such as sky diving, electronic video gaming tournaments, kayaking and so forth. The Coordinator focused on the five pillars of Comprehensive Airman Fitness and enhanced the social skills of millennial Airmen. Under this new business model, the Coordinator could lead 
airmen to participate in the new programs administered by the new variety of national and local businesses that would replace NAF activities that most millennial airmen have never supported.

\section{CONCLUSION}

There is no better time than now for the Air Force to develop a new services business model. The consequences of not changing this antiquated model that is two generations behind the times could result in an eventual loss of the Air Force's MWR programs due to a lack of Department of Defense funding. Additionally, a failure to adapt to the millennial generation by bringing in more national retail and food operations could pose recruiting and retention challenges once the economy recovers "since millennial airmen are not as partial to serving in the military as past generations". ${ }^{20}$

The Air Force should decide if it prefers PPV partnerships, TPLA partnerships, or a combination of the two types of arrangements. Then the Air Force should request AAFES take lead on forming these community business partnerships with national and local businesses as determined by surveying Airmen and their families. This new services business model will accomplish what Services Transformation did not -- align the needs and desires of today's Airmen with businesses they will actually utilize. Furthermore, this new model has the potential to annually save the Air Force tens of millions of NAF and APF dollars in manpower costs; APF building infrastructure and maintenance costs; and lost NAF revenue with current figures over $\$ 4,650,000$ per year. This new model will ease the Air Force's fiscal burden and more effectively allow for the force support squadrons to accomplish their doctrinal mission: "to energize Airmen and build a sense of community."

It will take courage for senior Air Force leadership to close failing "non-core" NAF activities just as much as it will take courage for AAFES to form community business 
partnerships. Implementing this approach will require leadership, risk taking, innovation, and resolve since there will be roadblocks. Edits can be provided for outdated instructions and legislation can be updated, if necessary. Air Force (services) leadership must determine how to use this strategic approach to get to "yes" instead of responding with every possible reason why this vision cannot be accomplished. Maintaining the status quo will ensure senior Air Force leaders agonize over readiness, modernization, and unfortunately, a missed opportunity to improve Airmen quality of life and morale for decades to come. The time to implement this new business model is now. 


\section{Notes}

${ }^{1}$ Farrell, Jr., Lawrence P. National Defense Magazine. November 2011.

http://www.nationaldefensemagazine.org/archive/2011/November/Pages/\%E2\%80\%98Gentleme n,WeHaveRunOutOfMoney;NowWeHavetoThink\%E2\%80\%99.aspx (accessed December 03, 2013).

${ }^{2}$ Headquarters United States Air Force A1. "Today's Airmen." October 06, 2013.

${ }^{3}$ Tilghman, Andrew. "Interest in Service Waning Among America's Youth." Air Force Times. Springfield: Gannett Government Media Corp, January 27, 2014.

${ }^{4}$ Secretary of the Air Force. "Air Force Instruction 65-106 (Financial Management)." Appropriated Fund Support of Morale, Welfare, and Recreation (MWR) and Nonappropriated Fund Instrumentalities (NAFIS). SAF/FM, May 6, 2009, 11.

${ }^{5}$ United States Air Force Personnel Center Services Directorate. "Services Installation Support Financial Dashboard." September 2013.

${ }^{6}$ Secretary of the Air Force. "Air Force Instruction 34-262 (Services)." Services Programs and Use Eligibility. United States Air Force, June 27, 2002.

${ }^{7}$ United States Air Force Personnel Center Services Directorate. "Services Installation Support Financial Dashboard." September 2013.

${ }^{8}$ Dunn, Captain Matthew. "Services Transformation Program Management Review [PowerPoint Slides]." Air Force Personnel Center, 2013.

${ }^{9}$ Safer, Morley. CBS News (60 Minutes). May 23, 2008.

http://www.cbsnews.com/news/themillennials-are-coming/ (accessed May 1, 2014).

${ }^{10}$ Barkley Ad Agency (Jeff Fromm). Millennial Marketing. 2013.

http://millennialmarketing.com/who-are-millennials/ (accessed December 05, 2013).

${ }^{11}$ Garton, Christie. (Entrepreneur) - Marketers: The 3 Differences Between Millennial Guys and Gals. October 30, 2013.

http://m.entrepreneur.com/article/229574?cam=Partners\&ctp=Outbrain\&cdn=Article

(accessed December 05, 2013).

${ }^{12}$ Headquarters United States Air Force A1. "Today's Airmen." October 06, 2013.

${ }^{13}$ Pellerin, Cheryl. U.S. Department of Defense American Forces Press Service - "Service Chiefs Detail 2014 Sequestration Effects". September 13, 2013.

http://www.defense.gov/news/newsarticle.aspx?id=120825 (accessed January 17, 2014).

${ }^{14}$ Mills, Donna. Air Force Offers Potential Model for MWR Programs. Air Force News. August 22, 2013. http://www.af.mil/News/ArticleDisplay/tabid/223/Article/466940/air-force-offerspotential-model-for-future-mwr-programs.aspx $\quad$ (accessed August 22, 2013).

${ }^{15}$ Headquarters United States Air Force A1. "Services Business Model Dilemma." 2012.

${ }^{16}$ Keppler, Jeffrey. Public Private Ventures (Department of Defense Concessions Committee). Washington D.C., November 2013.

${ }^{17}$ Keppler, Jeffrey. Public Private Ventures (Department of Defense Concessions Committee). Washington D.C., November 2013.

${ }^{18}$ United States Air Force Personnel Center Services Directorate. "Services Installation Support Financial Dashboard." September 2013.

${ }^{19}$ Air Force A1. "A1 Transformation." Air Force Program Directive 07-11. February 15, 2008.

${ }^{20}$ Tilghman, Andrew. "Interest in Service Waning Among America's Youth." Air Force Times. 
Springfield: Gannett Government Media Corp, January 27, 2014. 


\section{Bibliography}

Army \& Air Force Exchange Service. Building on Success - 2012 Annual Report. AAFES, 2012.

Barkley Ad Agency (Jeff Fromm). Millennial Marketing. 2013.

http://millennialmarketing.com/who-are-millennials/ (accessed December 05, 2013).

Cecil, Michael. AFPC/SVOFP. "Bullet Background Paper on Food Transformation Initiative." November 1, 2013.

Dunn, Captain Matthew. "Services Transformation Program Management Review [PowerPoint Slides]." Air Force Personnel Center, 2013.

Fanning, Acting Secretary of the Air Force Eric and Air Force Chief of Staff Mark Welsh III. "Future Air Force Organization." Washington DC: United States Air Force, July 23, 2013.

Farrell, Jr., Lawrence P. National Defense Magazine. November 2011. http://www.nationaldefensemagazine.org/archive/2011/November/Pages/\%E2\%80\%98G entlemen,WeHaveRunOutOfMoney;NowWeHavetoThink\%E2\%80\%99.aspx (accessed December 03, 2013).

Garton, Christie. (Entrepreneur) - Marketers: The 3 Differences Between Millennial Guys and Gals. October 30, 2013. http://m.entrepreneur.com/article/229574?cam=Partners\&ctp=Outbrain\&cdn=Article (accessed December 05, 2013).

Grammer, Jon. "Services Transformation." Air Force Personnel Center, October 30, 2012.

Headquarters United States Air Force A1. "A1 Transformation." Air Force Program Directive 07-11. February 15, 2008.

Headquarters United States Air Force A1. "Air Force A1 Force Support Squadron Implementation Plan." 2008.

—. "Services Business Model Dilemma." 2012.

—. "Today's Airmen." October 06, 2013.

Hoachlander, Eric. Virtual Fitness Kiosks Set Up at 66 Locations. Air Force News. September 11, 2013. http://www.af.mil/mobile/News/tabid/252/Article/467089/virtual-fitnesskiosks-set-up-at-66-locations.aspx (accessed September 11, 2013). 
Joint Chiefs of Staff. Joint Publication 1 - Doctrine for the Armed Forces of the United States. March 25, 2013.

Jones, Darrell Lt Gen. "Services Transformation - Corona South Briefing [PowerPoint Slides]." 2012.

Keppler, Jeffrey. Public Private Ventures (Department of Defense Concessions Committee). Washington D.C., November 2013.

Mills, Donna. Air Force Offers Potential Model for MWR Programs. Air Force News. August 22, 2013. http://www.af.mil/News/ArticleDisplay/tabid/223/Article/466940/air-forceoffers-potential-model-for-future-mwr-programs.aspx (accessed August 22, 2013).

Moseley, Air Force Chief of Staff T. Michael. "Services Functions in the Air Force." March 30, 2006.

Office of Secretary of Defense Public Affairs Guidance. "Implementation of Sequestration." March 1, 2013.

Pellerin, Cheryl. U.S. Department of Defense American Forces Press Service - "Service Chiefs Detail 2014 Sequestration Effects". September 13, 2013. http://www.defense.gov/news/newsarticle.aspx?id=120825 (accessed January 17, 2014).

Safer, Morley. CBS News (60 Minutes). May 23, 2008. http://www.cbsnews.com/news/themillennials-are-coming/ (accessed May 1, 2014).

Secretary of the Air Force. "Air Force Instruction 34-262 (Services)." Services Programs and Use Eligibility. United States Air Force, June 27, 2002.

-. "Air Force Instruction 65-106 (Financial Management)." Appropriated Fund Support of Morale, Welfare, and Recreation (MWR) and Nonappropriated Fund Instrumentalities (NAFIS). SAF/FM, May 6, 2009.

Tilghman, Andrew. "Interest in Service Waning Among America's Youth." Air Force Times. Springfield: Gannett Government Media Corp, January 27, 2014.

United States Air Force Eaker Center for Professional Development. "A1 Occupational Knowledge, Skills, Abilities and Competencies [PowerPoint Slides]." Maxwell Air Force Base, Alabama, 2013.

United States Air Force Personnel Center Services Directorate. "Services Installation Support Financial Dashboard." September 2013. 
United States Air Force Personnel Center/Services Transformation Team. "Talking Paper on Services Transformation Project." July 2013.

United States Air Force Public Affairs Office. "Air Force Community Partnership Initiative." May 30, 2013.

United States Air Force Services Agency. "Home Station Readiness Training - Resource Management Block I - APF/NAF Accounting Guide." 2009.

United States Army. U.S. Army MWR. December 2013.

http://www.armymwr.org/commander/aboutmwr.aspx (accessed December 02, 2013).

United States General Accounting Office. Defense Management - Better Guidance Needed in Selecting Operating Methods for Name-Brand, Fast-Food Restaurants. Report to the Chairman and Ranking Minority Member, Special Oversight Panel on Morale, Welfare, and Recreation, Committee on Armed Services, House of Representatives, Washington, D.C.: United States General Accounting Office, 2001.

Walden, Lieutenant Colonel Lori. "Air Force Community Partnerships - Tabletop Exercises Kickoff." March 19, 2013.

Zander, Steve. "Air Force Community Partnership Initiative: Public-Public; Public-Private Partnerships (P4)." September 26, 2013. 